\title{
Occupational Health Hazards among Commercial Motorcyclists in Ahmadu Bello University, Zaria.
}

\author{
Yunusa, U. ${ }^{\mathrm{a}}$, Lawal, U.B. ${ }^{\mathrm{a}}$, Idris A. ${ }^{\mathrm{a}}$, Garba, S.N ${ }^{\mathrm{b}}$. \\ ${ }^{a}$ Department of Nursing Sciences, Faculty of Medicine, Bayero University, Kano. \\ ${ }^{b}$ Department of Nursing Sciences, Faculty of Medicine, Ahmadu Bello University, Zaria
}

\begin{abstract}
Commercial motorcycles have posed a lot of hazards usually in form of accidents which are often serious and fatal. Using $A B U$, Zaria as a case study, this survey aims to assess the occupational health hazards among motorcyclists. A cross sectional survey design was used for the study. Questionnaires were administered to 216 respondents. Majority of whom were in the age group of 30-34 years with mean age of 31.7 years. $83.4 \%$ had formal education ranging from primary to tertiary education and $74.5 \%$ of the respondents are of Hausa/Fulani extraction, 55.6\% have been involved in an occupational hazard out of which $86.7 \%$ had road traffic accidents. Major outcome of accidents include bruises, lacerations and fractures. It is therefore concluded that accidental injury is a major form of occupational health hazard associated with commercial motorcyclists and recommended that the school management, motorcyclists and other stakeholders have a role to play in reducing these hazards.
\end{abstract}

Key Words: OCCUPATIONAL HEALTH, HAZARD, COMMERCIAL MOTORCYCLE

\section{Introduction}

As civilization developed, new kinds of work created new dangers, people began to notice that certain occupations influence the workers health. The field of occupational health and safety is concerned with lessening these dangers. Occupational health is the promotion and maintenance of the highest degree of physical, mental and social wellbeing of workers in all occupations by preventing departures from health, controlling risks and the adaptation of work to people and people to their jobs (International Labor Organization ILO/World Health Organization WHO, 1995 \& Agius, 2006 ).

Hazard is something that can cause harm if not controlled. The outcome is the harm that results from the uncontrolled hazard. Common workplace hazard groups include environmental agents/hazards, physical agents, chemical agents, biological hazards and psychosocial issues (Joseph, 2006 ).

A commercial motorcycle also referred to as Achaba/Okada in Nigeria is a situation where by a motorcycle rider carry a passenger for hire. It is one of the chief modes of transport in Nigeria and by far the most common form of informal transport system in the country. The popularity and widespread acceptance of okada has rapidly risen in recent years. Unfortunately, the rise of okada has been accompanied by increased levels of high risk behaviour and accidents on the Nigerian roads as a result they have come under heavy flak culminating in legislation restricting or prohibiting their operations in some Nigerian cities ( Cervero, 2005 ).

Commercial motorcycle/ Okada is the second most used mode of transportation in Nigeria (Ibitayo,2012) as according to respondents, motorcycles covers $24 \%$ of all modes of transportation. Surveys by Chauradi and Delhome (2013), estimates that although bikes are still a minority transportation mode, the rate of motorcyclist commuters has slowly increased over the last decade in most developed countries. This probably results from road traffic congestion, waste of time, cost of other means of public transport and convenience (being readily available and fast) of motorcycles.

This increase in commercial motorcycle is associated with corresponding increase in hazards to both the riders and the passengers. According to Sunderlal, Adarsh and Pankaj (2007), motorcyclist are predisposed to a number of hazards which results into injuries and even deaths in severe cases. Such hazards are caused by factors which are categorized into 3 :

1. Environmental Factor: - This includes inadequate road networks and surfaces, less physical space, overcrowded road conditions and objects in the road.

2. Human Factor: - This includes poor visual acuity, impaired hearing, physical defect, negligence/ non use of personal protective measures, psychosocial problems, addiction and abuse of substance.

3. Machine Factor :- Bad maintenance and poor monitoring

The aforementioned factors predisposes the motorcyclists to hazards such as eye problems, thefts, ritual acts/kidnapping, impaired hearing ability and accidental injuries. The accidental injuries include bruises, lacerations, dislocation, fractures and even death in severe situations. With these hazards occurring in an academic environment, students and University staff are also involved thereby hindering effective teaching and 
learning process. It is as a result of these that the researchers seek to study the occupational health hazards among commercial motorcyclist in Ahmadu Bello University, Zaria.

\section{Statement Of Problem}

The rise of motorcycles as a means of private, public and commercial urban transport is evident in many countries in sub-Saharan Africa (Abuhamoud, Rahmat and Ismail, 2011). This has posed a lot of hazards particularly accidents resulting in injuries and even death in severe cases to the motorcyclists, passengers and pedestrians. Between 20 to 50 million people globally are estimated to be injured or disabled each year due to road traffic accidents (WHO, 2002).

In 2004, there were 14,279 reported road traffic crashes in which 5351 people were killed and 16,897 people were injured in Nigeria. An increasingly large proportion of these burdens were due to motorcycle crashes, many of which were used for commercial commuting (FRSC, 2006). Furthermore, motorcycle riders are 30 times more likely than car occupants to die in a traffic crash and 8 times more likely to be injured (NHTSA, 2007).

$\mathrm{ABU}$, Zaria, is the largest University in sub Saharan Africa with a very busy main campus and having motorcycles as a major means of public transport. To the knowledge of the researchers, studies on occupational health hazards among motorcyclists have not been conducted within the University. Reckless driving, lack of concern for road signs by commercial motorcyclists, and disregard of motorcyclists by pedestrians is a common occurrence within the campus. These predisposes the motorcyclists, passengers and pedestrians to hazards such as bruises, lacerations, dislocations and even fractures in severe situation. It is based on aforementioned that this study was conducted to assess the occupational health hazards among commercial motorcyclists in $\mathrm{ABU}$, Zaria.

\section{AIM OF STUDY}

The main aim of this study is to assess the occupational health hazards which commercial motorcyclists are exposed to in Ahmadu Bello University, Zaria.

\section{OBJECTIVES OF THE STUDY}

1. To determine the nature of hazards which motorcyclists are exposed to.

2. To identify the major causes of hazards associated with motorcyclists

3. To determine the prevalence of hazards among the motorcyclists.

4. To identify the outcome of hazards which motorcyclists are exposed to.

\section{SIGNIFICANCE OF STUDY}

The result of the study will be used to enlighten and educate the motorcyclists on the existence of potential hazards they are exposed to, make the causes of such hazards known to the motorcyclists, facilitate the government/school management to provide facilities, set policies, strategies and devices of curbing such hazards. The study will also enhance the motorcyclists to use safety measures, effective utilization of available health services and means of preventing such hazards. Learning and teaching process in the university will be enhanced if recommendation from this study is accepted and implemented by stakeholders.

\section{Literature Review}

Commercial motorcycle is one of the chief modes of transport in Nigeria and by far the most common form of informal transport system in the country. The popularity and widespread acceptance of commercial motorcycles have rapidly risen in recent years. Unfortunately, the rise of commercial motorcycles has been accompanied by increased levels of high risk behavior and accidents on Nigerian roads (Cervero, 2005). The rise of okada has been related to high rates of crime in cities throughout Nigeria particularly in the city centers, urban slums and red light districts. This criminal activities range from (the typical) snatching of personal effects (example: mobile phones, purses, bags) to abduction, grand larceny and (political) killings.

The World Health Organization Report (2003) reveals that accidents and injuries are global problems. These are common in developed and developing countries. Injuries represent $12 \%$ of global burden of diseases, The third most common cause of death amongst 1-40 years old and more than 20 million people are severely injured or killed on the world road each year.

In recent years, commercial motorcyclists have come to bridge the huge gap in most cities across the country. However, this is not without the dangers they pose to themselves, passengers and other road users (Muazu and Aliyu, 2008). In a study conducted in Zaria by Muazu and Aliyu (2008) to assess the prevalence of psychoactive substance use among commercial motorcyclist, 200 commercial motorcyclists were interviewed, majority $(55.5 \%)$ of them were in the age group of $21-25$ years with a mean age of 25.4 years. All the 
motorcyclists were males, $60.5 \%$ had no formal education, $79.5 \%$ are of Hausa extraction and $69 \%$ worked for more than 10 hours per day.

The rise of commercial motorcycles in Nigeria is associated with a wide range of views by both customers and the motorcyclists regarding commercial motorcycles. In a study conducted by Cervero (2005) in Yola a medium sized city in the north-eastern state of Adamawa, Nigeria, the results which elicited information from 160 motorcyclists shows that about $88 \%$ of the okada riders were aged between 18 and 30 years and only $74 \%$ of them received formal education of any form.

Despite the risk associated with commercial motorcycles customers still patronize them. As a survey of okada customers in Akure, Ondo state revealed concerns over safety- as $61 \%$ of respondents felt operators drove too fast and $31 \%$ felt they drove too recklessly. Left with a few mobility options, many patronize okadas well knowing the significant risk involved (Cervero, 2005). This shows that if safer alternatives are sufficiently available people will go for them but in the absence of alternatives, efforts should be made to address the risky behaviours of motorcyclists.

Road traffic accidents among commercial motorcyclists are a frequent occurrence in this part of the country. There is need for public awareness campaigns on road safety education and health consequences of psychoactive substance use among commercial motorcyclists. It is further recommended that law enforcement agencies (NAFDAC, NDLEA and FRSC ) need to work in tandem so as to curb the problem of substance abuse in our society and reduce the rate of accidents on Nigerian roads( Aliyu and Muazu, 2008). Study conducted by Amoran, Eme, Giwa, \& Gbolahan (2005) shows that 136(45.5\%) of respondents have been involved in at least one accident in the preceding year

Several reasons have been found to be associated with causing hazards to motorcyclists. Reports from various countries (Kenya, Uganda, Ethiopia, Tanzania, Ghana, South Africa, and Zimbabwe) show that most of the road crashes are largely due to a range of human error, road, and vehicle factors that include (1) speeding and perilous overtaking, (2) alcohol and drug abuse, (3) driver negligence and poor driving standards, (4) vehicle overload, (5) poor maintenance of vehicles, (6) bad roads and hilly terrain, (7) negligence of pedestrians, and (8) distraction of drivers (e.g., speaking on cell phones).( Peltzer, 2011)

In addition to findings from study above, other possible causes of hazards among motorcyclists include: road surface quality and features, level of visibility, rider distraction, and rider style may present elements of risk. (Broughton, Walker, Aldershot, 2009)

Results of study conducted by Ping Li, Li li, En cai, Lin zhang and Kai Lo (2008) in China to assess the improper motorcycle helmet use in provincial areas of a developing country shows that a large proportion of both drivers and passengers (34\% and $71 \%$ respectively) did not wear helmet. Three quarter of whom were males and mostly $(87.2 \%)$ between the ages of $25-30$ years.

Common hazards among motorcycles includes: rough roads, gravel on pavement, edge breaks, expansion joints, open bridge joints, animals (hitting animals), slick surfaces, standing water, snow and ice, railway tracks/crossings and debris or objects on the roads. (Michon, 2013).

Risky behaviours among motorcycle riders, chaotic traffic and road design faults accounted for most of the motorcycle crashes. (Oluwadiya, Kolawole, Adegbehingbe, Agodirin and Uwaezuoke, 2009).

A study conducted in Zaria reveals that a high prevalence of $59.5 \%$ of road traffic accidents which was associated with use of psychoactive drugs was found among the motorcyclists. Commonly identified psychoactive substance/ drugs used were; marijuana (Indian hemp) 25.8\%, solution 24.5\%, caffeine (kola) $15.8 \%$ and coffee $4.8 \%$. Keeping awake, suppression of fatigue and peer effect were the identified factors influencing psychoactive substance use.(Muazu and Aliyu, 2008).

In a survey conducted by Ukponmwan, Dawodu, Edema, \& Okojie,(2007 ) in Benin city Nigeria to find out the prevalence of pingueculum and pterygium among commercial motorcyclist. The age range of the motorcyclists was 18 - 65 years with a mean age of 34.9 years. Pterigium was present in 18 patients including 12 bilateral cases making a total of 30 eyes giving a prevalence rate of $12.5 \%$. The total number of indoor workers with pingueculum was 24 and it was present in 46 eyes giving a prevalence rate of $21.5 \%$.

\section{Research Design}

\section{Research Methology}

A cross sectional survey design was used to obtain information on occupational health hazards among motorcyclists in Ahmadu Bello University Zaria.

\section{Location Of Study}

Ahmadu Bello University is located in the ancient city of Zaria in Kaduna state. Zaria lies between latitude 11.07 and 12.00 degrees north and longitude of 07.44 and 08.00 east of the Greenwich meridian, 22.00 feet above the sea level. It is located a distance of about $962 \mathrm{Km}$ from the Atlantic ocean and about $50 \mathrm{Km}$ north 
of Kaduna, vegetation is that of guinea savannah with tropical continental climate housing two seasons (dry and rainy season). The major tribe is Hausa/Fulani and main religions are Islam and Christianity.

Ahmadu Bello University was founded on October $4^{\text {th }}, 1962$ as the university of northern Nigeria by the then northern region government and was taken over as a federal institution in 1975.

As stated in part (ii) of its principal law, the University was created to among other things produce a high level of man power, secure the diffusion of knowledge, research and community service in northern Nigeria, and Nigeria in general and to function as a centre of excellence. Ahmadu Bello University lies on about 7,000 hectares of land, with approximately 35,000 students, a very large main campus as well as a number of research institution.

Population Of Study

The target population comprise of all 720 registered motorcyclists in Ahmadu Bello University Zaria (Main campus).

\section{Sampling Technique And Sample Size}

A single stage cluster sampling was utilized to obtain information for the study. The sample was derived from the four main motorcycle parks within the campus which are main gate, north gate, social center and faculty of social sciences. A sample size of 216 which is equivalent to $30 \%$ of all the registered commercial motorcyclists operating in the university were selected while 54 respondent were allocated to each of the four motorcycle parks. All motorcycle riders present at the park during the time of survey were recruited until the required sample size for that park was reached.

\section{Method Of Data Collection}

Data for the study was collected by utilizing a well structured, pretested questionnaires. Some of the questionnaires were translated into Hausa (local language) for easy administration.

An explanation of the purpose of the study was made to the motorcyclists and then their consent was obtained to participate in the survey. Confidentiality of information provided by motorcyclists was assured. Data quality was ensured through on sight supervision and review of completed forms.

\section{Method Of Data Analysis}

Each completed subject survey form was reviewed for completeness prior to analysis. The data collected was analyzed using descriptive statistical methods through use of frequency distribution, mean and percentages.

\section{Results}

A total of 216 respondents were used for the study. Table 1 shows that Majority (29.6\%) of respondents were between age range 30-34 years, $70.8 \%$ were married and $83.4 \%$ had formal education ranging from primary to tertiary education while majority $(74.5 \%)$ are of Hausa/Fulani extraction.. Table 2 shows that the most common hazard associated with motorcyclists is accident (76.9\%). Table 3 shows that $55.6 \%$ of the respondents were involved in an occupational hazard while $44.4 \%$ of the respondents have not been involved in occupational health hazard. Causes of hazards as shown in Table 4 include over speeding $(31.5 \%)$ and bad road condition (14.3\%), other causes of hazards includes alcohol/drugs/psychoactive substance, over work/ stress, disregard for use of personal protective equipment, untrained riding, lack of patience, negligence for use of road signs and inadequate regulation for motorcycle riders. Table 5 shows that $66.7 \%$ of those that were involved in accidents sustained bruises, $23.3 \%$ had lacerations, 3.3\% had visual impairment(pterigium) and $6.7 \%$ had fractures.

Table 1. Demographic Data

\begin{tabular}{|l|l|l|}
\hline Age range/years & Frequency & Percentage \\
\hline $20-24$ & 31 & 14.4 \\
\hline $25-29$ & 53 & 24.5 \\
\hline $30-34$ & 64 & 29.6 \\
\hline $35-39$ & 32 & 14.8 \\
\hline 40 and above & 36 & 16.7 \\
\hline Total & $\mathbf{2 1 6}$ & $\mathbf{1 0 0}$ \\
\hline Marital status & & \\
\hline Married & 153 & 70.8 \\
\hline Single & 53 & 24.5 \\
\hline Divorced & 8 & 3.7 \\
\hline Widower & 2 & 0.9 \\
\hline
\end{tabular}




\begin{tabular}{|l|l|l|}
\hline Total & $\mathbf{2 1 6}$ & $\mathbf{1 0 0}$ \\
\hline Educational qualification & & \\
\hline No formal education & 8 & 3.7 \\
\hline Primary & 60 & 27.8 \\
\hline Secondary & 84 & 38.9 \\
\hline Tertiary & 36 & 16.7 \\
\hline Qur'anic & 28 & 12.9 \\
\hline Total & $\mathbf{2 1 6}$ & $\mathbf{1 0 0}$ \\
\hline Tribe & & \\
\hline Hausa & 161 & 74.5 \\
\hline Igbo & 17 & 7.9 \\
\hline Yoruba & 8 & 3.7 \\
\hline Others & 30 & 13.9 \\
\hline Total & $\mathbf{2 1 6}$ & $\mathbf{1 0 0}$ \\
\hline
\end{tabular}

Table 2. Nature Of Hazards Associated With Commercial Motorcyclists

\begin{tabular}{|l|l|l|}
\hline Forms of hazards & Frequency & Percentage \\
\hline Accident & 166 & 76.9 \\
\hline Ritual/kidnap & 12 & 5.5 \\
\hline Theft & 25 & 11.6 \\
\hline Eye problem(pterigium) & 13 & 6.0 \\
\hline Total & $\mathbf{2 1 6}$ & $\mathbf{1 0 0}$ \\
\hline
\end{tabular}

TABLE 3. PREVALENCE OF HAZARDS

\begin{tabular}{|l|l|l|}
\hline Occupational hazards & Frequency & Percentage \\
\hline Involved & 120 & 55.6 \\
\hline Not involved & 96 & 44.4 \\
\hline Total & $\mathbf{2 1 6}$ & $\mathbf{1 0 0}$ \\
\hline
\end{tabular}

TABLE 4. CAUSES OF HAZARDS

\begin{tabular}{|l|l|l|}
\hline Causes of hazards & Frequency & Percentage \\
\hline Bad road condition & 32 & 14.3 \\
\hline Over speeding & 68 & 31.5 \\
\hline Overwork/stress & 4 & 1.9 \\
\hline Alcohol/drugs/psychoactive substance) & 16 & 7.4 \\
\hline $\begin{array}{l}\text { Disregard for use of personal protective } \\
\text { equipment }\end{array}$ & 12 & 5.6 \\
\hline Untrained riding & 4 & 1.9 \\
\hline Negligence for use of road signs & 12 & 5.6 \\
\hline Lack of patience & 20 & 9.3 \\
\hline Disregard for motorcyclists by pedestrians & 12 & 5.6 \\
\hline Inadequate regulation & 12 & 5.6 \\
\hline Disregard by automobiles & 8 & 3.7 \\
\hline Reckless driving & 16 & 7.4 \\
\hline Total & $\mathbf{2 1 6}$ & $\mathbf{1 0 0}$ \\
\hline
\end{tabular}

TABLE 5: OUTCOME OF HAZARDS OUTCOME OF HAZARD

\begin{tabular}{|l|l|l|}
\hline Outcome of hazard & Frequency & Percentage \\
\hline Fractures & 8 & 6.7 \\
\hline Bruises & 80 & 66.7 \\
\hline Laceration & 28 & 23.3 \\
\hline Visual impairment & 4 & 3.3 \\
\hline Total & $\mathbf{1 2 0}$ & $\mathbf{1 0 0}$ \\
\hline
\end{tabular}

\section{Discussion Of Findings}

A total of 216 respondents were used for the study. Table 1. shows that $24.5 \%$ and $29.6 \%$ of the respondents were between age range of 25-29 and 30-34 years respectively. Hence, $54.1 \%$ of the respondents are between age range of 25-34 years with a mean age of 31.7 years. This findings is in line with study carried out by Ukponmwan, et al, (2007) in Benin City where the mean age of the respondents was 34.9 years. Also study conducted by Amoran et al, (2005) in Igbora, Oyo State shows that the mean age of the respondents is 27.4 years.

Table 1. also shows that majority (38.9\%) of the respondents had secondary school education. the study also shows that $83.4 \%$ of the respondents had formal education ranging from primary, secondary and tertiary education. This result is in contrast with that carried out by Muazu and Aliyu (2008) in Zaria which shows that $60.5 \%$ of the motorcyclists had no formal education. However, the finding is in line with that conducted by Cervero (2005) in Yola which shows that $74 \%$ of them received formal education. The study setting has a great 
influence on the level of education of respondents, as study conducted in areas with institutions of higher learning have more educated respondents compared to other settings.

In relation to ethnic group table 1. shows that majority (74.5\%) of the respondents are Hausa. This is in line with study conducted by Muazu and Aliyu (2008) in Zaria which shows that 79.5\% of the respondents are of Hausa extraction. These findings are strongly related to the fact that majority of the population in Zaria are Hausa/Fulani.

Based on response to major form of hazard associated with commercial motorcyclists, Table 2 revealed that most of the respondents (76.9\%) were of the view that accident is the major form of hazard, other types of hazards includes ritual act/kidnapping, theft and eye problem. This is in line with the World Health Organization Report (2003) which says that accidents and injuries are global problems and are common in developed and developing countries. Injuries represent $12 \%$ of global burden of disease. The third most common cause of death amongst 1-40 years old more than 20 million people are severely injured or killed on the world road each year.

Table 3. shows that $55.6 \%$ of the respondents have been involved in an occupational hazard, $86.7 \%$ of which was accident while $13.3 \%$ had eye problem. This is almost in line with study conducted by Amoran et al (2005) in Igbora which shows that $45.5 \%$ of the respondents have been involved in at least one accident in the preceding years. Study conducted by Ukponmwan et al (2007) shows that the prevalence of pterygium among motorcyclists was $12.5 \%$.

On causes of hazards among motorcyclists, Table 4. shows that the major cause of hazards among motorcyclists include bad road condition, over speeding, over-work, use of alcohol/psychoactive substances, reckless driving, negligence for use of road signs, and lack of patience by the motorcyclists. Majority (69.9\%) of the respondents were of the view that over speeding, bad road condition, reckless driving, use of psychoactive substance and lack of patience are the major causes of accidents among motorcyclists. Study conducted by Muazu and Aliyu (2008) in Zaria shows that 59.5\% of road traffic accidents among motorcyclists was associated with use of psychoactive substances. Also, according to Sunderlal, Adarsh and Pankaj (2007), the causes of occupational health hazards among motorcyclists include drunk or drugged riding, unlicensed and untrained riding poor road conditions, over speeding and lack of use of personal protective equipments. Furthermore, findings from this study is also similar to study conducted by Peltzer in 2011 which reveals that causes of motorcyclists hazards include speeding and perilous overtaking, alcohol and drug abuse, driver's negligence and poor driving standards, vehicle overload, poor maintenance of vehicles, bad roads and hilly terrain, negligence of pedestrians, and distraction of drivers (e.g., speaking on cell phones).

Table 5. shows that majority (66.7\%) of the respondents involved in road traffic accidents sustained bruises, $23.3 \%$ had laceration and $6.7 \%$ had fracture to the limb. This is in line with study conducted by Muazu and Aliyu (2008) in Zaria which shows that the commonest types of injuries sustained by the respondents were bruises and lacerations (62.5\%) and fractures of upper and lower limbs (10.5\%). Also, study conducted by Oluwadiya (2004) at Obafemi Awolowo Teaching Hospital Ile Ife showed that injuries to limb occurred in $79.3 \%$ of patients who reported to the emergency unit of the hospital. Result is also similar to findings from study conducted by Zabeu, Zovico, Perira and Tucci, (2013) which shows that open fractures generated 11 percent of the outcome from road traffic accidents amongst motorcyclists.

\section{Conclusion And Recomendations}

This study showed that there is an increase in level of education and use of personal protective equipment among the motorcyclists in ABU Zaria compared to previous studies in other parts of the country. Despite these, accident is still the major form of hazard among the motorcyclists. Some identified causes of such accidents include poor road condition, negligence for use of safety measures, reckless driving, use of psychoactive substances and disregard for motorcyclists by pedestrians. This has made the motorcyclists susceptible to injuries such as laceration, bruises and even fracture in severe situation.

In line with the findings of this study, it is recommended that the school (university) management should ensure that the road network within the main campus are rehabilitated and maintained from time to time. Education and enlightenment sessions should be provided to the motorcyclists on road safety measures. Regular monitoring of the activities of motorcyclists to ensure that they abide with safety measures such as use of personal protective equipment, abiding to road signs and avoidance of over speeding. Tri-cycles can be provided as an alternative mode of transport as it may be safer than motorcycles. Motorcyclists should be made aware of the availability of health care service within the University whenever they require medical services. 


\section{References}

[1]. Abuhamoud, M. A., Rahmat, R. A. O. K., \& Ismail, A. (2011). Transportation and its concerns in Africa: A review. The Social Sciences, 6(1), 51-63.

[2]. Agius, R. (2006). Safety and Consumer protection. available at http://en.wikipedia.org/occuaptionalsafetandhealth, retrieved on $20^{\text {th }}$ Jun. 2009.

[3]. Amoran, E. Eme, O., Giwa, A. \& Gbolahan, B.(2005). Road safety practices among commercial motorcyclists. International quantity of Community Health Education. 24(1),55-64.

[4]. Broughton, P., Walker, L. \& Aldershot, A (2009) Motorcycling and leisure: Understanding the recreational Power Two Wheeler rider. Book reviews / Tourism Management (2011).32, 457-462

[5]. Cenvero, R. (2005). Informal transport in the developing world. West African Journal of Medicine 61(14), 414-420.

[6]. Chauradi, N. \& Delhome, P. (2013). Cyclists and drivers in road interaction: a comparison of Perceived crash risk. Accident Analysis and Prevention 50: 1176-1184

[7]. Clark, J.\& Corlett, G. (2007). Reforms in health systems in India. Indian Journal of Community Medicine: 27(3):99-105.

[8]. Federal Road Safety Commission FRSC, (2006). 2005 Annual report. Abuja.

[9]. Joseph, L. (2006). Current Occupational and Environmental Medicine. $4^{\text {th }}$ edition, New York McGraw-Hill Professional.

[10]. Michon, K. (2013). Motorcycle Accidents: Roads Hazards. Available at http://www.legal-encyclopedia/motorcycle-accidentsroad-hazards-30331-2html, retrieved on $6^{\text {th }}$ Oct. 2013

[11]. Mu'azu, M., \& Aliyu, A. (2008). Prevalence of psychoactive substance use among commercial motorcyclists, Annals of African Medicine, 24(2),78-93.

[12]. NHTSA, (2007). Traffic Safety Facts 2005. Washington, DC: National Highway TrafficSafety Administration

[13]. Oluwadiya, I. (2004). Motorcycle limb injuries in a developing country. West African Journal of Medicine, 74 (11), $612-615$.

[14]. Oluwadiya, K.S., Kolawole, O.O., Adegbehingbe, A.A., Agodirin, O. \& Uwaezuoke, S.C. (2009). Motorcycle crash characteristics in Nigeria: implication for control. Accident Annalysis and Prevention, 41, 294-298.

[15]. Peltzer, K. (2011) .Road Use Behavior in Sub-Saharan Africa Human Sciences Research Council, Pretoria, South Africa, and University of the Free State, Bloemfontein, South Africa.

[16]. Ping, L. L., Li, L. G., En, C.Q., Lin, Z.A., \& Kai, L.S., (2008). Improper motorcycle helmet use in provincial areas of a developing country. Accident analysis and prevention, 40, 1937-1942.

[17]. Sunderlal, Adarsh, \& Pankaj (2007). Textbook of Community Medicine: Preventive and Social Medicine. New Delhi India: CBS Publishers.

[18]. Ukponmwan,C.U., Dawodu, O.A.,, Edema, O.F. \& Okojie, O.(2007).Prevalence of Pterygium and pingueculum among motorcyclists in Nigeria. East Africa Medical Journal, 84(11),516-521.

[19]. United States Highway Safety Authority (2004). Occupational hazards and consequences. available at http://en.wikipedia.org/wiki/okaa retrieved on $27^{\text {th }}$ June 2009.

[20]. World Health Organization (2002). Early detection of health impairment in Occupational Exposure to health hazards. Technical report series. Geneva: WHO Report No. 571.

[21]. World Health Organization (2003) Psychosocial factors at work and their relation to health. Geneva: WHO Bulletin 33(11-12).

[22]. World Health Organization (2004). Technical Report series. Geneva: WHO Report No. 923.

[23]. World Health Organization/World Bank (2004). World Report on Road Traffic Injury prevention. Geneva: WHO.

[24]. World Health Organization. (2007). Adhoc committee on health research relating to future intervention options investing in health research and development. Geneva. 